University of Nebraska - Lincoln

DigitalCommons@University of Nebraska - Lincoln

1988

\title{
Metabolism as a Basis for Differential Atrazine Tolerance in Warm-Season Forage Grasses
}

\author{
Monte R. Weimer \\ Beth A. Swisher \\ Kenneth P. Vogel \\ University of Nebraska-Lincoln, kvogel1@unl.edu
}

Follow this and additional works at: https://digitalcommons.unl.edu/usdaarsfacpub

Weimer, Monte R.; Swisher, Beth A.; and Vogel, Kenneth P., "Metabolism as a Basis for Differential Atrazine Tolerance in Warm-Season Forage Grasses" (1988). Publications from USDA-ARS / UNL Faculty. 1884. https://digitalcommons.unl.edu/usdaarsfacpub/1884

This Article is brought to you for free and open access by the U.S. Department of Agriculture: Agricultural Research Service, Lincoln, Nebraska at DigitalCommons@University of Nebraska - Lincoln. It has been accepted for inclusion in Publications from USDA-ARS / UNL Faculty by an authorized administrator of DigitalCommons@University of Nebraska - Lincoln. 


\section{Allen Press \\ Weed Science Society of America}

Metabolism as a Basis for Differential Atrazine Tolerance in Warm-Season Forage Grasses Author(s): Monte R. Weimer, Beth A. Swisher and Kenneth P. Vogel

Source: Weed Science, Vol. 36, No. 4 (Jul., 1988), pp. 436-440

Published by: Weed Science Society of America and Allen Press

Stable URL: http://www.jstor.org/stable/4044664

Accessed: 26-10-2015 19:32 UTC

Your use of the JSTOR archive indicates your acceptance of the Terms \& Conditions of Use, available at http://www.jstor.org/page/ info/about/policies/terms.jsp

JSTOR is a not-for-profit service that helps scholars, researchers, and students discover, use, and build upon a wide range of content in a trusted digital archive. We use information technology and tools to increase productivity and facilitate new forms of scholarship. For more information about JSTOR, please contact support@jstor.org. 


\title{
Metabolism as a Basis for Differential Atrazine Tolerance in Warm-Season Forage Grasses ${ }^{1}$
}

\author{
MONTE R. WEIMER, BETH A. SWISHER, and KENNETH P. VOGEL ${ }^{2}$
}

\begin{abstract}
Atrazine metabolism was studied in four warmseason forage grasses to determine if metabolism was the basis for differential atrazine tolerance among the grasses. Big bluestem and switchgrass are atrazine tolerant while indiangrass and sideoats grama are atrazine susceptible in the seedling stage. Metabolism of atrazine in big bluestem and switchgrass occurred primarily by glutathione conjugation. The major metabolic product isolated from indiangrass and sideoats grama was the $N$-deethylated metabolite of atrazine. Glutathione conjugation by big bluestem and switchgrass occurred at a faster rate than $N$-dealkylation of atrazine in indiangrass and sideoats grama. Differential tolerance to atrazine among the grasses studied was probably due to the metabolic route by which they detoxify atrazine and the rate of metabolism for that specific route. Intraspecific differences in atrazine tolerance in indiangrass were due to the amount of metabolite produced in relationship to the amount of parent atrazine remaining in the shoot tissue. The more tolerant indiangrass lines had a higher metabolite to parent atrazine ratio than susceptible lines. This study confirmed differences in seedling atrazine tolerance of four indiangrass lines observed in previous greenhouse studies. Nomenclature: Atrazine, 6-chloro- $N$-ethyl$N^{\prime}$-(1-methylethyl)-1,3,5-triazine-2,4-diamine; big bluestem, Andropogon gerardii Vitman; switchgrass, Panicum virgatum L.; indiangrass, Sorgbastrum nutans (L.) Nash; sideoats grama, Bouteloua curtipendula (Michx.) Torr.

Additional index words. Metabolism, selectivity, Andropogon gerardii, Panicum virgatum, Sorghastrum nutans, Bouteloua crutipendula.
\end{abstract}

\section{INTRODUCTION}

Warm-season grasses are often difficult to establish because of competition from summer annual weed species $(19,20)$. Successful establishment of warm-season perennial forage grasses has been facilitated with the use of atrazine (11). However, atrazine susceptibility among warm-season forage grass species differs and precludes the establishment of mixed species stands $(1,11)$. Mixed species stands can be beneficial because they provide warm-season grasses that may compete better with weeds and provide adaptability over a broad range of environmental conditions.

Several levels of atrazine susceptibility among warm-season grasses were demonstrated (11). Switchgrass and big bluestem

\footnotetext{
${ }^{1}$ Received for publication November 10, 1987, and in revised form February 26, 1988. Published as Paper No. 8524, J. Ser., Nebraska Agric. Exp. Stn.

${ }^{2}$ Grad. Res. Asst., Former Asst. Prof., and Res. Geneticist, Dep. Agron. and USDA-ARS, Univ. Nebraska, Lincoln, NE 68583, respectively. Current address of senior author: Dep. Agron., Univ. Wisconsin, Madison, WI 53706
}

seedlings were tolerant to applications of $3.4 \mathrm{~kg} / \mathrm{ha}$ atrazine. Indiangrass showed some tolerance but not enough to allow the use of atrazine. Sideoats grama and sand lovegrass, Eragrostis trichodes (Nutt.) Wood, exhibited no tolerance to atrazine applications. Big bluestem and switchgrass produced higher forage yields when atrazine was used for weed control.

Detoxication of atrazine can occur by three pathways: $N$-dealkylation, 6-hydroxylation, and glutathione conjugation or a combination of these pathways $(8,9,14)$. Both hydroxyatrazine and the glutathione conjugate of atrazine are considered to be nonphytotoxic metabolites (16). $\mathrm{N}$ dealkylation produces molecules that are less phytotoxic than the parent herbicide molecule $(13,16)$.

Atrazine $N$-dealkylation, hydroxylation, and peptide conjugation (glutathione conjugates and their catabolites) occurred in 53 grass species (6). Reaction rates varied greatly among the species. The species with known tolerance to atrazine formed the glutathione conjugate. The order of tolerance of five grass species was identical to their ability to metabolize atrazine (17). The order of tolerance and metabolism was corn, Zea mays L., > fall panicum, Panicum dicbotomiflorum Michx., = large crabgrass, Digitaria sanguinalis (L.) Scop., > giant foxtail, Setaria faberii Herrm., $>$ oats, Avena sativa L.

Much evidence exists that different varieties of crop plants can react differently to certain herbicides (12). Differential tolerance to a herbicide among cultivars or biotypes of a species could result from a differential rate of metabolism of that herbicide (4). Differential metabolism of metribuzin, 4-amino-6-(1,1-dimethylethyl)-3-(methylthio)-1,2,4-triazin$5(4 H)$-one, was responsible for the observed differences in metribuzin susceptibility in two soybean [Glycine max (L.) Merr.] cultivars (10)

The studies presented in this paper were conducted to determine the metabolism of atrazine in four warm-season grasses important in the Great Plains of the United States. Big bluestem, switchgrass, indiangrass, and sideoats grama were examined to determine if atrazine metabolism is responsible for differential tolerance. Also studied were several breeding lines of indiangrass known to vary in their tolerance to atrazine. The objective of the latter study was to determine if metabolism was responsible for observed intraspecific atrazine tolerance.

\section{MATERIALS AND METHODS}

Interspecific atrazine tolerance. Leaf disks were obtained from greenhouse-grown 'Pawnee' big bluestem, 'Nebraska 54' indiangrass, 'Trailway' sideoats grama, and 'Pathfinder' switchgrass at the late boot stage. The greenhouse was maintained at $26 \pm 5 \mathrm{C}$. Supplemental lighting maintained a day length of $14 \mathrm{~h}$ of $1000 \mu \mathrm{E} \cdot \mathrm{m}^{-2} \cdot \mathrm{s}^{-1}$ photosynthetically active 
radiation. Each sample consisted of $0.5 \mathrm{~g}$ of $3-\mathrm{mm}$-diameter disks. Leaf disks were placed in a $50^{-} \mathrm{ml}$ erlenmeyer flask containing $7 \mathrm{ml}$ of $0.5 \mathrm{M}$ phosphate buffer at $\mathrm{pH} 6.5$ with $0.1 \%(\mathrm{v} / \mathrm{v})$ nonionic surfactant ${ }^{3}$ and $0.11 \mu \mathrm{Ci}$ of uniformly ring-labeled ${ }^{14} \mathrm{C}$ atrazine $\left(62 \mu \mathrm{Ci} / \mathrm{mg}\right.$ ). ${ }^{14} \mathrm{C}$ atrazine used in this study was purified by thin-layer chromatographic separation. Assay of ${ }^{14} \mathrm{C}$ activity showed less than $0.3 \%$ of the radioactivity present as impurities. The samples were placed on a rotary shaker at $100 \mathrm{rpm}$ for 6, 24, or 48 hours.

Leaf disks were harvested by filtration of the phosphate buffer and surface washing of the leaf disks with distilled water. The leaf disks were homogenized in methanol, and the homogenized residues were removed from the methanol by filtration. Radioactivity in subsamples of the phosphate buffer, methanolic leaf disk extracts, and wash water was quantified by liquid scintillation spectrometry. The remaining samples were evaporated to dryness in vacuo at $35 \mathrm{C}$. Acetonitrile was utilized as an azeotrope to facilitate the evaporation of the water. These concentrated samples were stored at $-10 \mathrm{C}$ for no longer than 2 weeks before metabolite characterization by thin-layer chromatography. The activity remaining in the leaf disk tissue was quantified by oxidation $^{4}$ of the residue and subsequent counting by liquid scintillation spectrometry.

The concentrated samples of both the methanol extracts and the media were subjected to analysis by thin-layer chromatography. Twenty $\mu$ l subsamples were placed on precoated $0.25-\mathrm{mm}$-thick silica gel plates. Two solvent systems were utilized in the analysis. Solvent $I$ consisted of methylene chloride and ethyl acetate $(4: 1, \mathrm{v} / \mathrm{v})$ and solvent II contained $N$-butanol, glacial acetic acid, and water $(12: 3: 5$, $\mathrm{v} / \mathrm{v} / \mathrm{v})(14)$. Solvent II was used to separate the polar products of atrazine metabolism, the peptide conjugates, and hydroxyatrazine. The plates were allowed to develop to a solvent front of $14.5 \mathrm{~cm}$. Location and quantitation of radioactivity on the plate were determined by beta-imaging ${ }^{5}$. Analytical standards ${ }^{6}$ (atrazine, monodealkylated atrazine, didealkylated atrazine, and hydroxyatrazine) were cochromatographed in these solvent systems to identify the ${ }^{14} \mathrm{C}$ unknowns. Location of the analytical standards was determined by ultraviolet light detection. Location of the glutathione conjugate was accomplished by reference to $R_{f}$ values of previous studies (2).

Intraspecific atrazine tolerance. Seed from seven 'Holt' indiangrass plants whose progeny differed in seedling atrazine tolerance in previous greenhouse tests were used in this study (7). The parent plants were grown in an isolated, open-pollinated polycross nursery that contained a total of 53 genotypes

\footnotetext{
${ }^{3} \mathrm{X}-77$ principal functioning agents are alkylarylpolyoxy-ethylene glycols, free fatty acids, and isopropanol (90\%).

${ }^{4}$ Packard Model 306 sample oxidizer. Packard Instrument Co., Inc., Downers Grove, IL 60515.

${ }^{5}$ Bid-System-300 Beta Imaging Scanner. Bioscan, Inc., Washington, DC.

${ }^{6}$ Analytical standards and ${ }^{14} \mathrm{C}$ atrazine supplied by CIBA-GEIGY Corp., Greensboro, NC.
}

that were not previously selected for atrazine tolerance. Seed was harvested from each plant in this polycross nursery and the seed from each individual plant comprised a halfsib family or line. Each genotype was replicated twice in the polycross nursery by clonal propagation and hence two half-sib families or lines were produced from each genotype or clone. The two half-sib families of a genotype could have been pollinated by a different mix of pollen because of the location of the individual plants or ramets of each genotype (clone) within the polycross nursery. Two of the seven lines, 3305A and 3305B, were from different plants of the same genotype, 3305. Seed from individual indiangrass lines were planted at a density of 35 seed/container in $30-\mathrm{ml}$ plastic cups containing washed quartz sand. Plants were watered with half-strength Hoagland's solution (5). When the plants reached $2 \mathrm{~cm}$ in height, $0.11 \mu \mathrm{Ci}{ }^{14} \mathrm{C}$ atrazine was added to the sand in $4 \mathrm{ml}$ of half-strength Hoagland's solution. Plants were harvested and extracted at 2,4 , or 6 days after application of ${ }^{14} \mathrm{C}$ atrazine. Shoots were cut at the surface level of the sand. Shoot heights and fresh weights were measured. Roots were removed from the sand by two distilled water rinses. Root fresh weights were also determined. The atrazine remaining in the sand was extracted with methanol and added to the washing extracts. This accounted for the unabsorbed fraction of the applied atrazine.

Extraction, quantification, and identification of the ${ }^{14} \mathrm{C}$ atrazine in the individual plant sections were completed by using the procedure described in the leaf disk experiment. However, only solvent I was used in the separation by thin-layer chromatography since only minor quantities of hydroxyatrazine were detected in preliminary experiments. Washing extracts were also quantified to account for all of the applied ${ }^{14} \mathrm{C}$ atrazine. A metabolite:atrazine ratio was calculated by determining the amount of absorbed atrazine that was metabolized and that remained as parent atrazine.

Statistical analyses. In both studies two replications were included and each experiment was repeated. All data were subjected to standard analysis of variance. The data were combined because of nonsignificant treatment-by-experiment interactions. Regression analysis was used to calculate metabolite production in the interspecific study. Treatment means were separated at each extraction time by Duncan's multiple range test in the intraspecific study.

\section{RESULTS AND DISCUSSION}

Interspecific atrazine tolerance. In this study, all four grasses had at least minor quantities of each of the metabolites isolated. Big bluestem and switchgrass metabolized atrazine at a similar rate (Figure 1). The primary metabolic product isolated in these two grasses was peptide conjugates of atrazine (Figure 2). Only minor quantities of dealkylated products were formed in big bluestem and switchgrass (Figure 3).

The major metabolite produced in indiangrass and sideoats grama was an $N$-dealkylated product. The majority of the $N$-dealkylated product formed in indiangrass and 


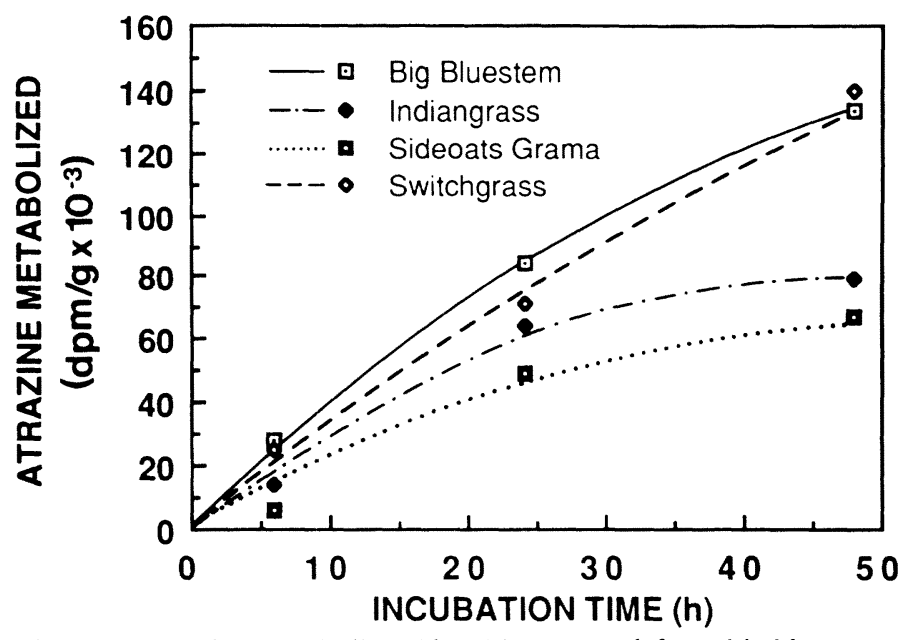

Figure 1. Atrazine metabolites $(\mathrm{dpm} / \mathrm{g})$ extracted from big bluestem, indiangrass, sideoats grama, and switchgrass leaf disks after application of ${ }^{14} \mathrm{C}$ atrazine. The respective best fit regression equations were: big bluestem, $\mathrm{y}=4390.8 \mathrm{X}-33.6 \mathrm{X}^{2}\left(\mathrm{r}^{2}=0.96\right)$; indiangrass $3456.6 \mathrm{X}-$ $37.5 \mathrm{X}^{2}\left(\mathrm{r}^{2}=0.98\right)$; sideoats grama, $y=2449.1 \mathrm{X}-21.6 \mathrm{X}^{2}\left(\mathrm{r}^{2}=0.98\right)$; switchgrass $\mathrm{y}=3279.8 \mathrm{x}-7.8 \mathrm{X}^{2}\left(\mathrm{r}^{2}=0.96\right)$.

sideoats grama was deethylated atrazine, 6-chloro- $N$-amino$N^{\prime}$-(1-methylethyl)-1,3,5-triazine-2,4-diamine. Indiangrass produced more deethylated atrazine than did sideoats grama. Mono- $N$-dealkylation only partially detoxifies atrazine $(13,16)$. Much smaller quantities of peptide conjugates were detected in indiangrass or sideoats grama than in big bluestem or switchgrass (Figure 2).

More total ${ }^{14} \mathrm{C}$ material (atrazine and metabolites) was present in big bluestem and switchgrass after $48 \mathrm{~h}$ of incubation compared to indiangrass and sideoats grama (Table

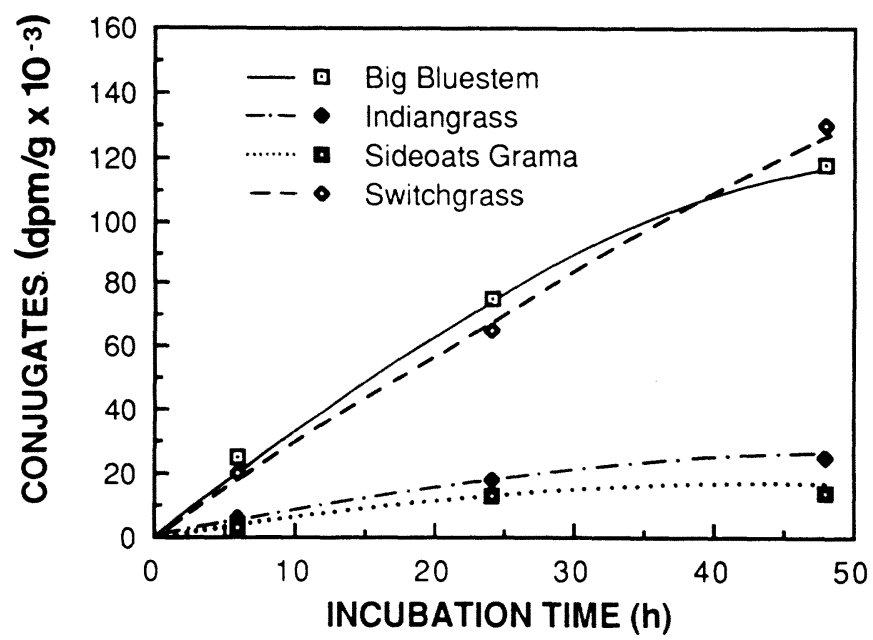

Figure 2. Peptide conjugates $(\mathrm{dpm} / \mathrm{g})$ extracted from big bluestem, indiangrass, sideoats grama, and switchgrass leaf disks after application of ${ }^{14} \mathrm{C}$ atrazine. The respective best fit regression equations were: big bluestem, $y=3946.3 x-31.1 x^{2} \quad\left(r^{2}=0.96\right)$; indiangrass, $y=1036.4 x-10.6 X^{2} \quad\left(r^{2}=0.93\right)$; sideoats grama, $y=762.3 x-9.7 X^{2}$ $\left(r^{2}=0.86\right)$; switchgrass, $y=2874 X-3.7 X^{2}\left(r^{2}=0.95\right)$.
1). More rapid atrazine metabolism in big bluestem and switchgrass would maintain a concentration gradient and thereby increase total atrazine uptake. The amount of parent atrazine in the leaf disks was similar for all four grasses (Table 1 ), indicating the the grasses had maintained a similar concentration of atrazine in the leaf disks despite differences in metabolism. Recovery of the applied ${ }^{14} \mathrm{C}$ atrazine was greater than $93 \%$ in all cases.

The high level of peptide conjugation in big bluestem and switchgrass suggests that big bluestem and switchgrass metabolize atrazine primarily by glutathione conjugation. Peptide conjugation represents total detoxication of the atrazine molecule (2). At an 8-h extraction time, Jensen et al. (6) reported similar results in big bluestem leaves infiltrated with ${ }^{14} \mathrm{C}$ atrazine. Big bluestem was reported to have formed $19.8 \%$ peptide conjugates and had $57.1 \%$ unaltered atrazine remaining in leaf sections.

Glutathione conjugation is mediated by the enzyme glutathione- $S$-transferase (2). Glutathione $S$-transferase (EC 2.5.1.18) has a specific requirement for the presence of both $N$-alkyl side chains (2). Frear et al. (2) detected little or no activity of glutathione $S$-transferase when monodealkylated atrazine derivatives were used as the substrate for the enzyme. The monodealkylated derivatives were the same as those isolated in indiangrass and sideoats grama in this study. Therefore, in concurrence with Frear et al. (2) deethylated atrazine in indiangrass and sideoats grama was apparently not reactive with glutathione $S$-transferase. Differences in rate and route of metabolism among the species used in this study probably were responsible for the differences in atrazine susceptibility previously observed in the field (10).

Intraspecific atrazine tolerance. Kube et al. (7) demonstrated that four of the indiangrass lines (3305A, 3305B, 1603,

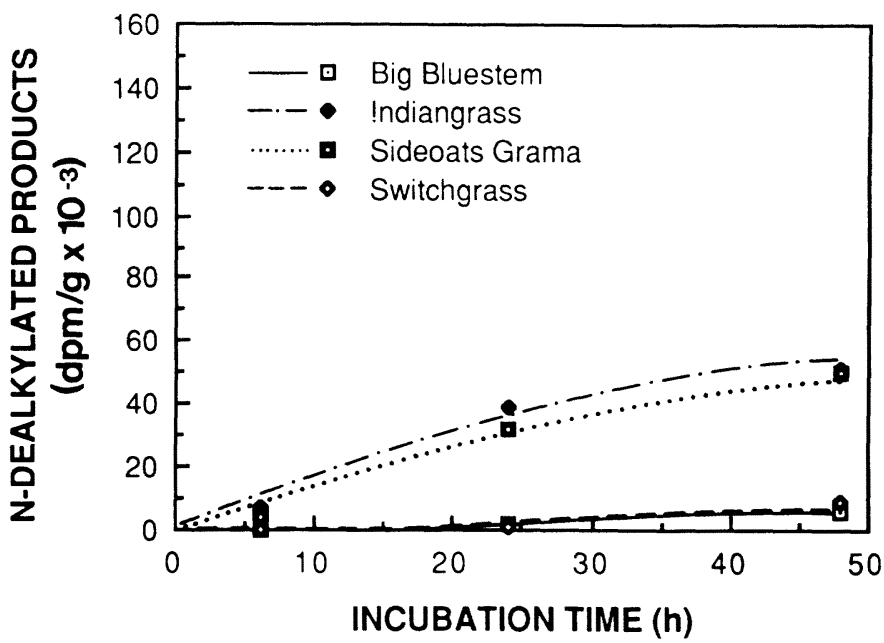

Figure 3. N-dealkylated metabolites $(\mathrm{dpm} / \mathrm{g})$ extracted from big bluestem, indiangrass, sideoats grama, and switchgrass leaf disks after application of ${ }^{14} \mathrm{C}$ atrazine. The respective best fit regression equations were: big bluestem, $y=19.7 X+2.0 X^{2}\left(r^{2}=0.63\right)$; indiangrass, $y=20.55 .1 x-20.2 x^{2} \quad\left(r^{2}=0.93\right) ;$ sideoats grama, $y=1498.2 x-$ $9.2 X^{2}\left(r^{2}=0.98\right)$; switchgrass, $y=-32.5 X+4.4 X^{2}\left(r^{2}=0.95\right)$. 
Table 1. Concentration of ${ }^{14} \mathrm{C}$ atrazine, atrazine metabolites, and percent atrazine metabolized in leaf disks of big bluestem, indiangrass, sideoats grama, and switchgrass.

\begin{tabular}{lccrc}
\hline Species & Time & \multicolumn{1}{c}{$\begin{array}{l}\text { Unaltered } \\
\text { atrazine }\end{array}$} & $\begin{array}{c}\text { Atrazine } \\
\text { metabolized }\end{array}$ & $\begin{array}{c}\text { Percent } \\
\text { metabolized }\end{array}$ \\
\hline & $(\mathrm{h})$ & $-\left(\mathrm{dpm} / \mathrm{g} \times 10^{-3}\right)$ & & $(\%)$ \\
Big bluestem & 6 & $78.2 \pm 3.8^{\mathrm{a}}$ & $28.4 \pm 4.9$ & 26.6 \\
& 24 & $74.4 \pm 4.9$ & $84.5 \pm 6.9$ & 53.2 \\
& 48 & $59.6 \pm 5.8$ & $133.6 \pm 16.8$ & 69.2 \\
Indiangrass & 6 & $89.2 \pm 11.3$ & $13.8 \pm 1.3$ & 13.4 \\
& 24 & $84.8 \pm 8.5$ & $63.9 \pm 4.3$ & 43.0 \\
& 48 & $52.1 \pm 10.1$ & $79.2 \pm 4.0$ & 60.3 \\
Sideoats grama & 6 & $43.1 \pm 3.7$ & $5.9 \pm 0.3$ & 12.0 \\
& 24 & $73.3 \pm 2.9$ & $49.8 \pm 3.9$ & 40.5 \\
& 48 & $68.2 \pm 4.5$ & $67.0 \pm 2.6$ & 49.6 \\
Switchgrass & 6 & $84.8 \pm 3.8$ & $25.1 \pm 2.3$ & 22.8 \\
& 24 & $71.6 \pm 10.2$ & $71.8 \pm 14.7$ & 50.0 \\
& 48 & $66.2 \pm 10.7$ & $140.3 \pm 9.0$ & 67.9 \\
\hline
\end{tabular}

${ }^{\mathrm{a}}$ Mean and standard error of the mean.

and 1008) had higher greenhouse tolerance to $3.4 \mathrm{mg} / \mathrm{kg}$ atrazine than the three more susceptible lines $(2305,2112$, and 0705). The two sets of lines will be referred to as tolerant and susceptible, respectively. Several growth parameters were measured to determine if they were associated with tolerance. In the present study no correlation was observed between tolerant and susceptible lines in shoot heights and shoot or root fresh weights (data not presented). Uptake of ${ }^{14} \mathrm{C}$ atrazine did not vary greatly among the indiangrass lines (Table 2). Recovery of applied ${ }^{14} \mathrm{C}$ atrazine was greater than $88 \%$.

Concentration of metabolites, compared to parent atrazine concentration, differs depending on whether the line was tolerant or susceptible to atrazine applications. Because ratios of metabolites remained constant between peptide conjugates and $\mathrm{N}$-dealkylated products, data are presented as a ratio of metabolites to parent atrazine. Tolerant lines had a higher ratio of metabolites to parent atrazine than did susceptible plants (Table 3 ). At the 2- and 4-day extraction times, tolerant lines had a metabolite:atrazine ratio greater than 1.0 and the susceptible lines were less than 1.0. Lines $3305 \mathrm{~A}$ and $3305 \mathrm{~B}$ differed slightly in their metabolism of atrazine. These plants came from the same genotype 3305 but differed in their pollen source. This indicates atrazine metabolism in indiangrass is determined at least partially by nuclear genes.

Root metabolism was not a major contributing factor to the overall metabolism by the plant. All lines had a low metabolite to parent atrazine ratio in the roots at all three extraction times (Table 3). Hydroxylation, catalyzed by benzoxazinone, is known to occur in the roots of atrazinetolerant plants such as corn (14). Sorghum, Sorgbum bicolor (L.) Moench., does not form hydroxy derivatives even though it is tolerant to atrazine (15). However, Thompson (18) found hydroxylation to occur in shattercane, Sorgbum bicolor (L.) Moench. This suggests that differences may exist in benzoxazinone levels among Sorgbum bicolor genotypes. The Sorgbastrum genus is closely related to the Sorgbum genus (3). Levels in benzoxazinone may also vary within the Sorghastrum genus just as they do within the Sorgbum genus. Data presented here show a low rate of root metabolism which does not suggest differences in benzoxazinone content in the indiangrass roots. It appears that differential tolerance among several indiangrass breeding lines is due to differential metabolism in the shoots. With different levels of metabolism occurring, potential for advancement in breeding atrazine tolerance in indiangrass may exist. Metabolism appears to be responsible for observed inter-and intraspecific atrazine tolerance.

Table 2. Concentration of ${ }^{14} \mathrm{C}$ atrazine and metabolites extracted from roots and shoots of seven indiangrass lines at 2 , 4, and 6 days after treatment with ${ }^{14} \mathrm{C}$ atrazine.

\begin{tabular}{|c|c|c|c|c|c|c|}
\hline \multirow[b]{3}{*}{ Plant genotype number } & \multicolumn{6}{|c|}{${ }^{14} \mathrm{C}$ atrazine and metabolites, days after treatment ${ }^{\mathrm{a}}$} \\
\hline & \multicolumn{3}{|c|}{ Shoots } & \multicolumn{3}{|c|}{ Roots } \\
\hline & 2 & 4 & 6 & 2 & 4 & 6 \\
\hline & & & $-(\mathrm{dpm} / \mathrm{g}$ & eight) & & - \\
\hline 1008 & $102933 \mathrm{a}$ & $75390 \mathrm{ab}$ & $94918 \mathrm{ab}$ & $66347 \mathrm{a}$ & 60561 a & $79830 \mathrm{ab}$ \\
\hline $3305 \mathrm{~B}$ & 93954 a & $65871 \mathrm{~b}$ & $65896 \mathrm{c}$ & $61559 \mathrm{a}$ & 59831 a & $55796 \mathrm{~b}$ \\
\hline $3305 \mathrm{~A}$ & 106852 a & $79065 \mathrm{ab}$ & $83339 \mathrm{bc}$ & 65243 a & $73571 \mathrm{a}$ & $63840 \mathrm{ab}$ \\
\hline 1603 & 105775 a & $74199 \mathrm{ab}$ & $83164 \mathrm{bc}$ & 94959 a & 75465 a & 95479 a \\
\hline 2112 & $106571 \mathrm{a}$ & $90141 \mathrm{a}$ & $106950 \mathrm{a}$ & $70668 \mathrm{a}$ & $70006 \mathrm{a}$ & $78748 \mathrm{ab}$ \\
\hline 0705 & 104095 a & $76280 \mathrm{ab}$ & $87167 \mathrm{~b}$ & 65517 a & $66031 \mathrm{a}$ & $63257 \mathrm{ab}$ \\
\hline 2305 & 92187 a & $63646 \mathrm{~b}$ & $81761 \mathrm{bc}$ & $73031 \mathrm{a}$ & $62194 \mathrm{a}$ & $61590 \mathrm{ab}$ \\
\hline
\end{tabular}

${ }^{\mathrm{a}}$ Means within columns followed by the same letter are not significantly different at the $5 \%$ level according to Duncan's multiple range test. 
WEIMER ET AL.: METABOLISM AS A BASIS FOR ATRAZINE TOLERANCE IN FORAGE GRASSES

Table 3. Ratio of metabolite concentration to parent atrazine in roots and shoots of seven indiangrass lines at 2,4 , and 6 days after treatment with ${ }^{14} \mathrm{C}$ atrazine.

\begin{tabular}{|c|c|c|c|c|c|c|}
\hline \multirow[b]{3}{*}{ Plant genotype number } & \multicolumn{6}{|c|}{ Ratio of metabolite/atrazine, days after treatment ${ }^{a}$} \\
\hline & \multicolumn{3}{|c|}{ Shoots } & \multicolumn{3}{|c|}{ Roots } \\
\hline & 2 & 4 & 6 & 2 & 4 & 6 \\
\hline & \multicolumn{6}{|c|}{ (metabolite/parent atrazine) } \\
\hline 1008 & $1.09 \mathrm{a}$ & $1.25 \mathrm{a}$ & $1.64 \mathrm{bcd}$ & $0.05 \mathrm{a}$ & $0.08 \mathrm{a}$ & $0.09 \mathrm{~b}$ \\
\hline $3305 \mathrm{~B}$ & $1.04 \mathrm{a}$ & $1.15 \mathrm{ab}$ & $1.77 \mathrm{bc}$ & $0.04 \mathrm{ab}$ & $0.05 \mathrm{~b}$ & $0.12 \mathrm{ab}$ \\
\hline $3305 \mathrm{~A}$ & $1.18 \mathrm{a}$ & $1.32 \mathrm{a}$ & $2.57 \mathrm{a}$ & $0.02 \mathrm{~b}$ & $0.08 \mathrm{a}$ & $0.12 \mathrm{ab}$ \\
\hline 1603 & $1.18 \mathrm{a}$ & $1.50 \mathrm{a}$ & $1.78 \mathrm{bc}$ & $0.03 \mathrm{ab}$ & $0.10 \mathrm{a}$ & $0.12 \mathrm{ab}$ \\
\hline 2112 & $0.75 \mathrm{~b}$ & $0.91 \mathrm{bc}$ & $1.20 \mathrm{de}$ & $0.05 \mathrm{a}$ & $0.08 \mathrm{a}$ & $0.13 \mathrm{ab}$ \\
\hline 0705 & $0.44 \mathrm{c}$ & $0.92 \mathrm{bc}$ & $1.28 \mathrm{cde}$ & $0.04 \mathrm{ab}$ & $0.11 \mathrm{a}$ & $0.16 \mathrm{a}$ \\
\hline 2305 & $0.59 \mathrm{bc}$ & $0.70 \mathrm{c}$ & $1.01 \mathrm{e}$ & $0.04 \mathrm{ab}$ & $0.09 \mathrm{a}$ & $0.14 \mathrm{ab}$ \\
\hline
\end{tabular}

\footnotetext{
${ }^{\mathrm{a}}$ Means within columns followed by the same letter are not significantly different at the $5 \%$ level according to Duncan's multiple range test.
}

\section{LITERATURE CITED}

1. Bahler, C. C., K. P. Vogel, and L. E. Moser. 1984. Atrazine tolerance in warm- season grass seedlings. Agron. J. 76:891-895.

2. Frear, D. S. and H. R. Swanson. 1970. Biosynthesis of S-(4ethylamino-6-isopropyl amino-2-s-triazino)glutathione: Partial purification and properties of a glutathione $\mathrm{S}$-transferase from corn. Phytochemistry 9:2123-2132.

3. Gould, F. W. and R. B. Shaw. 1983. Grass Systematics. Texas A \& M Univ. Press, College Station. 397 pp.

4. Hatzios, K. K. and D. Penner. 1982. Metabolism of Herbicides in Higher Plants. Burgess Publishing Co., Minneapolis. 142 pp.

5. Hoagland, D. R. and D. I. Arnon. 1950. The water culture method for growing plants without soil. California Agric. Exp. Stn. Circ. 347. $32 \mathrm{pp}$.

6. Jensen, K.I.N., G. R. Stephenson, and L. A. Hunt. 1977. Detoxification of atrazine in three gramineae subfamilies. Weed Sci. 29:70-73.

7. Kube, J., K. P. Vogel, and L. E. Moser. 1987. Genetic variability for seedling atrazine tolerance in indiangrass. Agron. Abstr. Am. Soc. Agron., Madison, WI. Page 68.

8. Lamoureux, G. L., R. H. Shimabukuro, H. R. Swanson, and D. S. Frear. 1970. Metabolism of 2-chloro-4-ethylamino-6isopropyl-amino-s-triazine (atrazine) in excised sorghum leaf sections. J. Agric. Food Chem 18:81-86.

9. Lamoureux, G. L., L. E. Stafford, R. H. Shimabukuro, and R. G. Zaylskie. 1973. Atrazine metabolism in sorghum: catabolism of glutathione conjugate of atrazine. J. Agric. Food Chem. 21: $1020-1030$.
10. Mangeot, B. L., F. E. Slife, and C. E. Rieck. 1979. Differential metabolism of metribuzin by two soybean (Glycine max) cultivars. Weed Sci. 27:267-269.

11. Martin, A. R., R. S. Moomaw, and K. P. Vogel. 1982. Warm season grass establishment with atrazine. Agron. J. 74:916920.

12. Martin, F. A. 1985. Genetic variability of response to plant growth regulators. Rev. Weed Sci. 1:64-73.

13. Shimabukuro, R. H. 1967a. Significance of atrazine dealkylation in root and shoot of pea plants. J. Agric. Food Chem. 14: $392-395$

14. Shimabukuro, R. H. 1967b. Atrazine metabolism and herbicidal selectivity. Plant Physiol. 42:1269-1276.

15. Shimabukuro, R. H. 1968. Atrazine metabolism in resistant corn and sorghum. Plant Physiol. 42:1269-1276.

16. Shimabukuro, R. H., W. C. Walsh, G. L. Lamoureux, and L. E. Stafford. 1973. Atrazine metabolism in sorghum: chloroformsoluble intermediates in the $\mathrm{N}$-dealkylation and glutathione conjugation pathways. J. Agric. Food Chem. 21:1031-1036.

17. Thompson, L., Jr., J. M. Houghton, F. W. Slife, and H. S. Butler. 1971. Metabolism of atrazine by fall panicum and large crabgrass. Weed Sci. 19:406-409.

18. Thompson, L., Jr. 1972. Metabolism of simazine and atrazine by wild cane. Weed Sci. 20:153-155.

19. Warnes, D. D. 1966. Warm-season grasses for tomorrow. Nebr. Farm, Ranch, and Home Q. 18:20-21.

20. Warnes, D. D., L. C Newell, and W. J. Moline. 1971. Performance evaluation of some warm-season prairie grasses in Nebraska environments. Nebr. Exp. Stn. Res. Bull. 241. 55 pp. 